Platelet-activating factor receptor (PAF-R) transcripts were analysed by reverse transcriptase-polymerase chain reaction in five human cancer cell lines derived from the breast (BT20, SKBR3 and T47D cells), the pancreas (Miapaca cells) and the bladder (5637 cells) in order to confirm the existence of a splice variant of the PAF-R transcript 2 . After cloning and sequencing, we confirmed its existence in all cell lines. It consisted of the PAF-R transcript 2 lengthening with 82 nucleotides from the $3^{\prime}$ end of exon 1 of the PAF-R gene. The role of this elongated form of the tissuetype PAF-R transcript in cell physiology remains to be elucidated.

Key words: Platelet-activating factor, Receptor, Transcript, Cell lines

\section{Expression of a splice variant of the platelet-activating factor receptor transcript 2 in various human cancer cell lines}

\author{
Ibtissam Youlyouz, Emmanuelle Magnoux, \\ Laurence Guglielmi and Yves Denizot ${ }^{\mathrm{CA}}$
}

Laboratoire d'Immunologie - UMR CNRS 6101, Faculté de Médecine, 2 rue du Docteur Marcland, 87025 Limoges, France

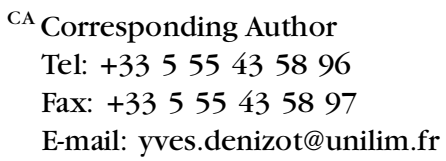

Platelet-activating factor is an inflammatory lipid molecule that acts through platelet-activating factor receptors (PAF-R) present on the membrane of responsive cells. ${ }^{1}$ The human PAF-R gene is encoded by a unique gene (exon 3) composed of two 5'-noncoding exons (exons 1 and 2). Thus, the PAF-R gene produces two different species of mRNA (i.e. transcripts 1 and 2) that generate a unique membrane PAF-R (Fig. 1A). It is well known that hematopoietic cells only express PAF-R transcript 1 (exons $1+3$ ) while transcripts 1 and 2 (exons $2+3$ ) are found in various organs such as the lung, spleen and heart. ${ }^{1-4}$ The presence of an elongated splice PAF-R variant in the 5'-untranslated region of the PAF-R transcript 2 has been documented in human colonic epithelial tumour cell lines. ${ }^{5}$ In these cells, the PAF-R transcript 2 was lengthened with 82 nucleotides from the 3 ' end of exon 1, generating a third PAF-R transcript. To our knowledge, no study has reported the existence of this elongated PAF-R transcript 2 in other cell types. The present study was thus designed to ensure its presence in human cancer cell lines derived from the breast, pancreas and bladder.

SKBR3, BT20 and T47D cells (three human breast cancer cell lines), Miapaca cells (a human pancreatic cancer cell line) and 5637 cells (a human bladder cancer cell line) were routinely grown in RPMI 1640 with $10 \%$ fetal calf serum (Life Technologies, Cergy Pontoise, France), penicillin $(100 \mathrm{U} / \mathrm{ml})$ and streptomycin $(100 \mu \mathrm{g} / \mathrm{ml})$ at $37^{\circ} \mathrm{C}$ in $5 \% \mathrm{CO}_{2}$ in air. Total RNA was extracted from SKBR3, BT20, T47D, Miapaca and 5637 cells with Tripure (Roche GmbH, Mannheim, Germany). Reverse transcription was carried out for $1 \mathrm{~h}$ with Superscript (Life Technologies, Cergy Pontoize, France), starting with $1 \mu \mathrm{g}$ of total RNA. The complementary DNA (cDNA) was then amplified by polymerase chain reaction (PCR). Reactions were carried out in $30 \mu 1$ of a mix made up of $8 \mathrm{mM} \mathrm{dNTP}$, $100 \mathrm{nM}$ of each primer, $1 \times$ Taq buffer and $0.2 \mathrm{U}$ of Taq Polymerase (Amersham Biosciences, Orsay, France). The PAF-R transcript 1 sense primers were 5'-ACTTGGTAGTGATACGCTCTGTTTCTT-3' (P1) and 5'-GACAGCATAGAGGCTGAG-GC-3' (P1'), the transcript 2 sense primer was 5'-CCTGAGCTCCCCGAGAAGTCA-3' (P2), and the antisense primer was 5'-TAGCCATTAGCAATGACCCC-3' (P3) (Fig. 1A). The constitutive expression of $\beta$-actin in all cell samples represented a positive control of reverse transcription (data not shown). As a negative control, the PCR reaction was performed with all reagents except the cDNA. PCR was performed on a Robocycler Gradient 96 (Stratagene, La Jolla, CA, USA). DNA was denatured for $180 \mathrm{sec}$ at $94^{\circ} \mathrm{C}$, then submitted to 35 cycles consisting of $94^{\circ} \mathrm{C}$ for $30 \mathrm{sec}$, $60^{\circ} \mathrm{C}$ for $60 \mathrm{sec}$ (with the $\mathrm{P} 1^{\prime}$ sense primer) or $64^{\circ} \mathrm{C}$ for $60 \mathrm{sec}$ (with P1 and P2 sense primers) and $72^{\circ} \mathrm{C}$ for $90 \mathrm{sec}$. A final elongation step was realised at $72^{\circ} \mathrm{C}$ for $10 \mathrm{~min}$. Products were then analysed on a $1.2 \%$ agarose gel stained with ethidium bromide. PCR products were cloned in Topo vector (Topo $^{\mathrm{TM}}$ 


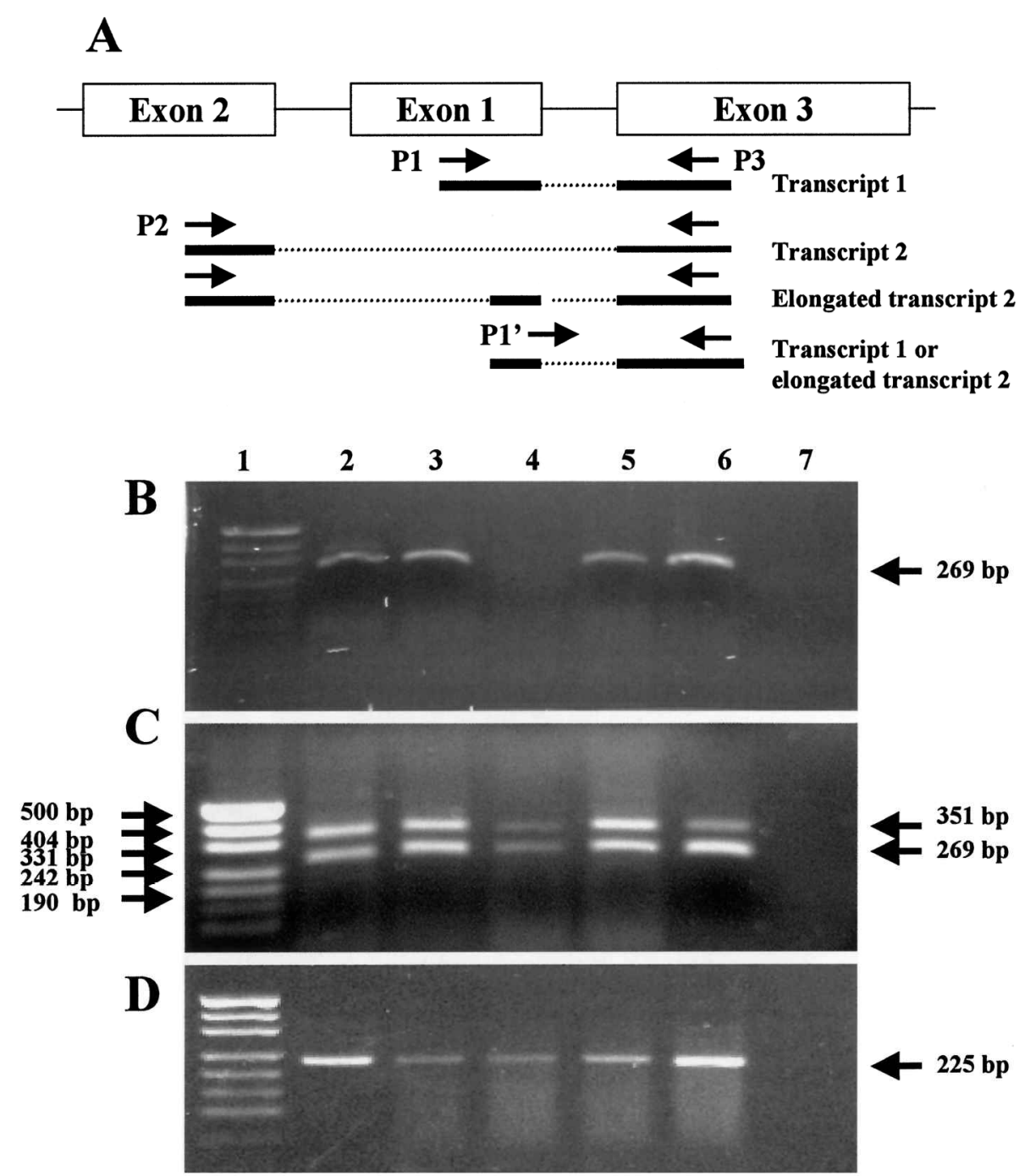

FIG. 1. Expression of PAF-R transcripts in human cancer cell lines derived from the breast (SKBR3, BT20 and T47D cells), the pancreas (Miapaca cells) and the bladder (5637 cells). (A) Schematic representation of the PCR analysis of PAF-R expression. (B) Expression of PAF-R transcript 1 (P1 and P3). (C) Expression of PAF-R transcript 2 and of its elongated form (P2 and P3). (D) Expression of PAF-R transcript 1 and/or of the elongated splice variant of PAF-R transcript 2 (P1' and P3). Lane 1, DNA size ladder; lanes 2-6, BT20, T47D, SKBR3, Miapaca and 5637 cells, respectively; lane 7, PCR blank.

cloning Kit; Invitrogen, Groningen, The Netherlands) and sequenced by the dideoxynucleotide method on an ABI Prism 310 DNA genetic analyser (Applied Biosystems, Foster City, CA, USA).

Using P1 and P3 primers, a 269 base pair (bp) fragment related to the PAF-R transcript 1 was amplified with BT20, T47D, Miapaca and 5637 cells, but not with SKBR3 cells (Fig. 1B). After cloning and sequencing, we found (data not shown) that the $269 \mathrm{bp}$ sequence was identical to the previously reported PAF-R transcript $1 .^{2}$ Using $\mathrm{P} 2$ and $\mathrm{P} 3$ primers, 269 and $351 \mathrm{bp}$ fragments were amplified from the five human cancer cell lines (Fig. 1C). After cloning and sequencing, we found (data not shown) that the 269 bp sequence was identical to the PAF-R transcript $2 .^{2}$ As previously reported by Kotelevets et al., ${ }^{5}$ our $351 \mathrm{bp}$ fragment was the $269 \mathrm{bp}$ fragment lengthened at the $3^{\prime}$ end of exon 2 by the following 82 nucleotides present at the $3^{\prime}$ end of exon 1: ACAGCATAGAGGCTGAGGCTGGGGCC AGGACCCAGACAGAGACACACGGTCACTGCAGCTGAAGCCGCTGCCCCTGCTACAG. Using $\mathrm{P} 1$ ' and $\mathrm{P} 3$ primers, a $225 \mathrm{bp}$ fragment related to the PAF-R transcript 1 was amplified, showing that the splice variant of the PAF-R transcript 2 may serve as a template for PCR amplification (Fig. 1D).

PAF-R transcript 1 , which is found in numerous hematopoietic cells, ${ }^{1,3,4}$ is detected in several nonhematopoietic cell lines such as BT20, T47D, Miapaca and 5637 cells, but not in SKBR3 cells. PAF-R transcript 2 (not detected in hematopoietic cells) is expressed by all these human cancer cell lines derived from the breast, pancreas and bladder. These five cell lines also express the splice variant of the PAF-R transcript 2 showing, for the first time, that its expression is not restricted to colonic epithelial 
tumor cell lines. ${ }^{5}$ So far, the physiological function of this elongated form of the PAF-R transcript 2 is unknown. As suggested by Kotelevets et al. ${ }^{5}$ it might provide additional flexibility in the control of PAF-R gene expression. It might have a potential role in the formation of secondary structures for a better translation initiation and/or for higher interactions with nuclear factors. Clearly further studies are required to clarify the role of the splice variant of the PAF-R transcript 2 in organ physiology.

\section{Acknowledgments}

The authors are grateful to the Ligue Nationale contre le Cancer (Comité de la Corrèze) for funding our project.

\section{References}

1. Ishii S, Shimizu T. Platelet-activating factor (PAF) receptor and genetically engineered PAF receptor mutant mice. Progr Lipid Res 2000; 39: 41-82.

2. Mutoh H, Bito H, Minami M, et al. Two different promoters direct expression of two distinct forms of mRNAs of human platelet-activating factor receptor. FEBS Lett 1993; 322: 129-134.

3. Desplat V, Dulery C, Faucher JL, Praloran V, Denizot Y. Metabolism and effect of platelet-activating factor on the growth of human myeloma cell lines. Cancer Lett 2000; 149: 7-13.

4. Desplat V, BesseA, Faucher JL, Praloran V, Denizot Y. Expression of plateletactivating factor receptor transcript- 1 but not transcript- 2 by human bone marrow cells. Stem Cells 1997; 17: 121-124.

5. Kotelevets L, Noë V, Bruyneel E, Myssiakine E, Chastre E, Mareel M, Gespach C. Inhibition by platelet-activating factor of Src- and hepatocyte growth factor-dependent invasiveness of intestinal and kidney epithelial cells. J Biol Chem 1998; 273: 14138-14145.

\section{Received 16 June 2002 \\ Accepted 2 July 2002}




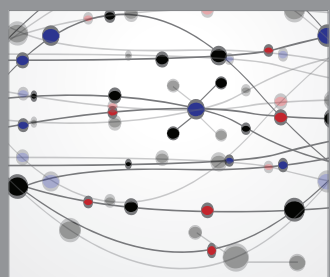

The Scientific World Journal
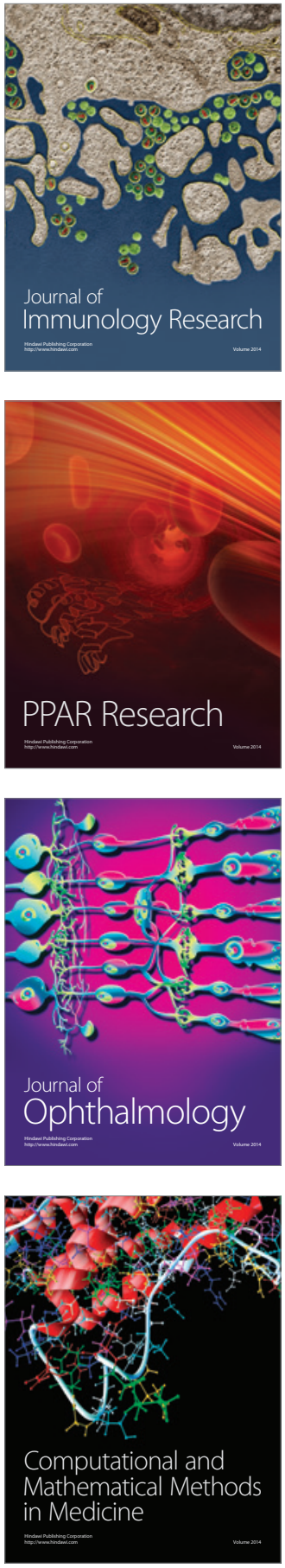

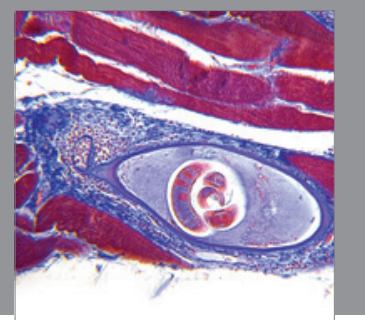

Gastroenterology

Research and Practice
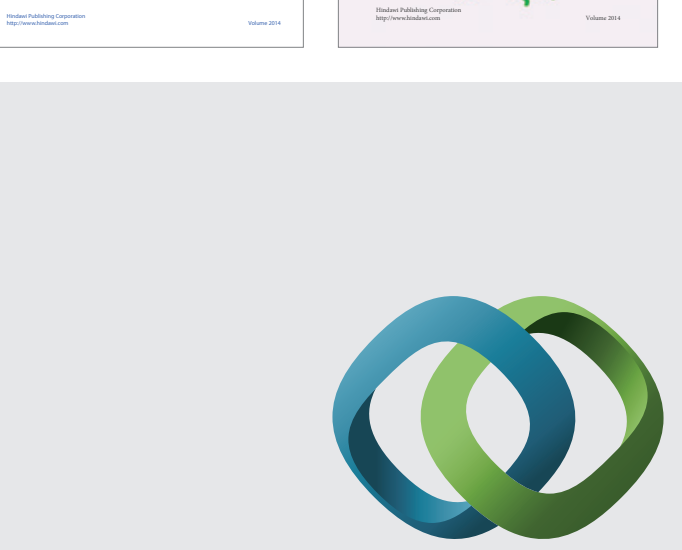

\section{Hindawi}

Submit your manuscripts at

http://www.hindawi.com
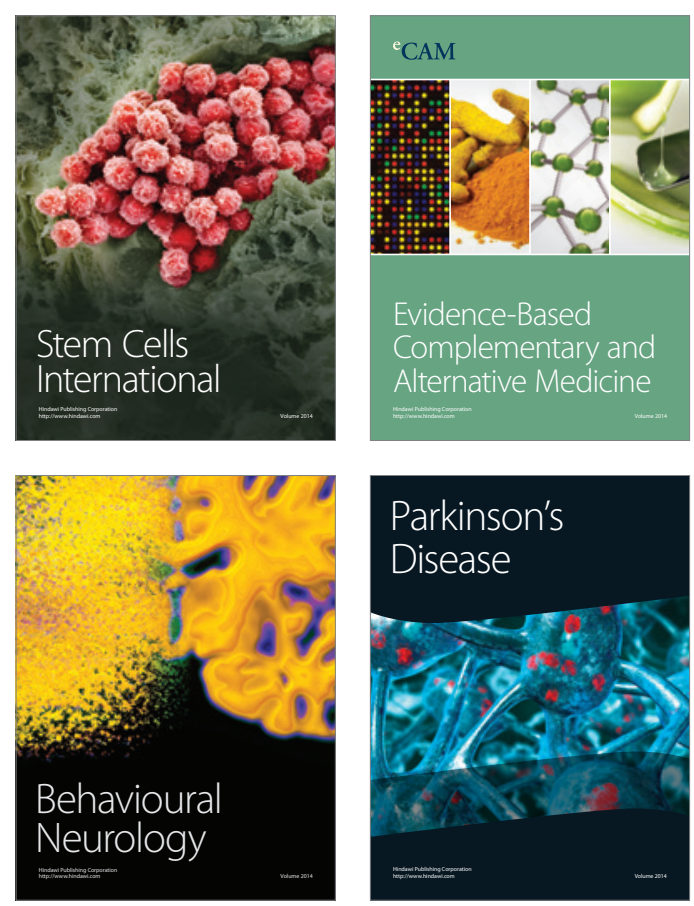

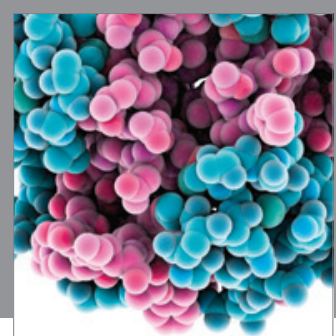

Journal of
Diabetes Research

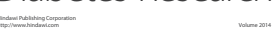

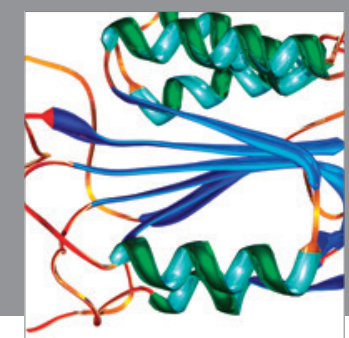

Disease Markers
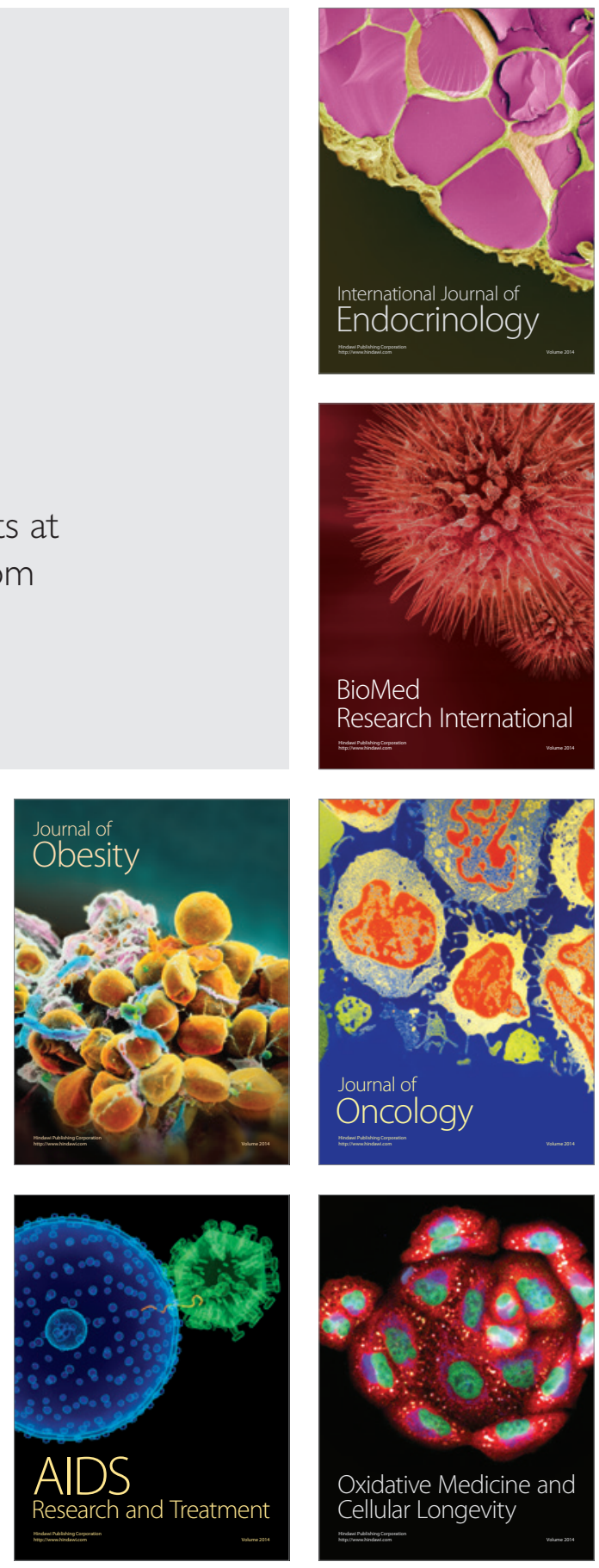